\title{
Harmful metals concentration in sediments and fishes of biologically important estuary, Bay of Bengal
}

\author{
Shanmugaasokan Lakshmanasenthil ${ }^{1 *}$, Thirumalairaj Vinothkumar ${ }^{1}$, Thipramalai Thankappan AjithKumar ${ }^{2}$, \\ Thangapandi Marudhupandi ${ }^{2}$, Dhaneesh Kottila Veettil ${ }^{2}$, Raghunathan Ganeshamurthy' ${ }^{2}$, Swagat Ghosh ${ }^{2}$ \\ and Thangavel Balasubramanian ${ }^{2}$
}

\begin{abstract}
Study on the accumulation level of heavy metals was conducted on sediment and fishes from estuaries of Bay of Bengal. Heavy metals were determined by using Inductively Coupled Plasma Optical Emission Spectrometer (ICP-OES) and the results were compared to permissible limits of WHO/USEPA. The accumulation patterns of Fe and $\mathrm{Cd}$ were found predominantly in all samples tested when correlated with other metals. It was found that the concentration of metals such as $\mathrm{Cd}(3.90 \pm 0.25 \mu \mathrm{g} / \mathrm{g}), \mathrm{Cr}(0.44 \pm 0.05 \mu \mathrm{g} / \mathrm{g}), \mathrm{Ni}(0.33 \pm 0.01 \mu \mathrm{g} / \mathrm{g})$, and $\mathrm{Mn}(1.1 \pm 0.11 \mu \mathrm{g} / \mathrm{g})$ were exceeding the permissible limit, whereas $\mathrm{Fe}, \mathrm{Co}, \mathrm{Pb}$, and $\mathrm{Zn}$ were found within the limit of WHO/USEPA at station 1. In station 2, $\mathrm{Cd}(16.5 \pm 0.4 \mu \mathrm{g} / \mathrm{g}), \mathrm{Mn}(0.67 \pm 0.11 \mu \mathrm{g} / \mathrm{g})$, and $\mathrm{Cr}(0.80 \pm 0.01 \mu \mathrm{g} / \mathrm{g})$ were exceeding the permissible limit, whereas $\mathrm{Fe}, \mathrm{Co}, \mathrm{Pb}, \mathrm{Ni}$, and $\mathrm{Zn}$ were found within the limit. This study emphasizes that $\mathrm{Cd}$ and $\mathrm{Mn}$ levels in both stations, are far higher than the acceptable values set by WHO/USEPA and may therefore present human health hazards. It is therefore mandatory to carry out extensive research to evaluate the possible environmental risk factors in the vicinity of both estuaries with respect to heavy metals.
\end{abstract}

Keywords: Environment, Estuary, Fishes, Health, Metal, Accumulation

\section{Introduction}

Estuarine ecosystems are highly productive because of rich nutrients received from the river runoff. One of the important roles of the estuaries is to provide the nursery ground for many young marine animals, and thus support a unique community of plants and animals, especially adapted for life in the coastal areas.

The major environmental problem of estuarine ecosystems is receiving various kinds of contaminants from the land. Majority of the industries at coastal area discharge the chemical effluents into the aquatic environment which in turn cause changes in habitat, species distribution, abundance, and bio-geo chemical cycles [1]. Wastes from urban, industries, and mining are the potential sources of heavy metal pollution [2]. The distribution of heavy metals in natural water and water

\footnotetext{
* Correspondence: lakshmanasenthil@gmail.com

${ }^{1}$ CMS College of Science and Commerce, Chinnavedampati (PO),

Coimbatore, Tamil Nadu, India

Full list of author information is available at the end of the article
}

bodies has widely been recognized as a major factor for biological risks $[3,4]$. As the spawning and nursery grounds of many marine organisms, including commercially valuable shrimp and fishes, which are plenty available in estuarine and coastal areas, they are directly affected by such influx of chemical contaminant into the ecosystem [5].

Fishes are on the top of the aquatic food chain and accumulate large amounts of metals from water and sediment. Sediments are known to be "Trace element traps" [6], because they eventually bind almost all the contaminants which enter the aquatic environment [4]. Heavy metals in sediments can lead to greater environmental problems when the contaminated sediments are resuspended and such metals are taken-up by filter feeders. Sediments can reflect the quality of the water system and can be used to detect insoluble contaminants [4]. Studies from field and laboratory experiments show that accumulation of heavy metals in tissues of animals depends mainly on metal concentration present in water.

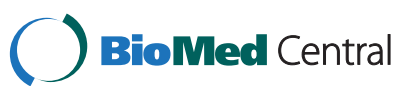


Heavy metals normally occurring in nature are not harmful to the environment, because they play an essential role in tissue metabolism and growth of plants and animals [7]. Metals like $\mathrm{Cu}, \mathrm{Zn}, \mathrm{Fe}, \mathrm{Co}, \mathrm{Mo}, \mathrm{Ni}, \mathrm{Si}$, and Sn become predominantly toxic when their level exceeds the limit, and $\mathrm{V}, \mathrm{Cd}, \mathrm{Pb}$, and $\mathrm{Hg}$ are prominently classified as toxic because of their detrimental effect even at low concentrations [8].

The estuaries selected for the present study are biologically important and economic hub of the people and expected to be polluted by industries and human activities. This leads to damage of food chain of this environment by those pollutants are toxic to aquatic animals and human those are live nearby area. Comprehensive studies related to the analyses of sediment and fishes around particular estuaries are limited. Therefore, the present study has been undertaken (i) to evaluate the extent of heavy metal contamination in sediment and edible part of fishes, (ii) to investigate the uptake of eight heavy metals in fishes and (iii) to understand the present condition of the ecosystems and to compile the baseline data for future monitoring.

\section{Methods}

\section{Study area}

Two stations (estuaries) lay in the Bay of Bengal (latitude of $10^{\circ} 55^{\prime} \mathrm{N}$; longtitude $79^{\circ} 52^{\prime} \mathrm{E}$; altitude of $8.85 \mathrm{~m}$ ) were selected and the coast has extensive areas of estuaries, mangroves, and brackish water lagoon which all have connection to the Bay of Bengal.

\section{Sample collection}

Two sampling sites (site 1 and site 2) were chosen in both stations. Site 1 (Stacknend), $2 \mathrm{~km}$ away from the mouth of the estuary and site 2 (Bar mouth) at the mouth of the estuary.

\section{Fish}

Fifteen fish samples representing each kind of fish species were collected from two stations. Fish species selected for analysis were Mugil cephalus, Oreochromis mossambicus, Arius caelatus, Lutjanus fulviflamma, Terapon jarbua and Chanos chanos. These are commercially and nutritionally important fish species. The samples were collected in sterile sample containers and kept in the laboratory deep freezer $\left(-20^{\circ} \mathrm{C}\right)$ to prevent deterioration till further analysis. Total length of fishes was measured and no significant differences were found among the species $(P>0.05)$ (Table 1). For each species, five representative samples with similar lengths were taken for the study.

\section{Sediment}

Sediment samples were collected at about $30 \mathrm{~cm}$ deep from sediment surface to obtain layer of the sediment according to Norhayati et al., (2007) [9]. Triplicate samples were collected from each site for the accuracy. Sampling tools were washed and dried with de-ionized water between the process of sampling, and the collected samples were stored at $4^{\circ} \mathrm{C}$.

\section{Determination of metal concentration Fish and sediment}

Nitric-perchloric acid digestion method was followed for analysis of heavy metal in sediment and edible tissue of fishes [10,11]. The fishes were descaled and dried at $80^{\circ} \mathrm{C}$ in an electric oven (Samsung) for $36 \mathrm{~h}$. It was then pulverized to powder using a dry homogenizer and stored. About $1 \mathrm{~g}( \pm 0.001 \mathrm{~g})$ of powdered sample was weighed and digested in $100 \mathrm{ml}$ glass beaker containing concentrated nitric acid $(20 \mathrm{ml})$ overnight. It was then mixed with $10 \mathrm{ml}$ of concentrated nitric acid and perchloric acid (4:1) solution. The samples were then subjected to complete dryness by placing on a hot plate. The ash thus obtained was made up to $20 \mathrm{ml}$ solution using ultrapure water from Milli- $\mathrm{Q}^{\bullet}$ water system with $20 \%$ nitric acid. The mixture was filtered using Whatman filter paper $(11 \mu \mathrm{m})$ and then the metal concentrations were determined using Inductively Coupled Plasma Optical Emission Spectromter (ICP-OES) (Software- WinLab 32; Perkin Elmer, Optima 2IOODV). The precision of the analytical procedure was checked by analyzing standard reference materials of commercially available standards (Merck KGCA, 64271 Damstadt, Germany, ICP-Multi element standard solution IV, 23 elements in nitric acid). The operating conditions and the wavelength selected for the analysis of different metals by ICP-OES are given in Tables 2 and 3 .

Sediment samples were air dried in the laboratory at room temperature, ground in fine mixture using mortar and pestle before sieving less than $2 \mathrm{~mm}$ mesh. The nitricperchioric acid digestion method was also followed for the analysis of the sediment.

\section{Statistical analysis}

All analysis was performed in triplicate and mean, SD values were calculated by $\mathrm{SPSS}^{\oplus}$ (v16) software for windows. Bray Curtis similarity index was carried out by Primer 6 (v6).

\section{Results}

In the present study, $\mathrm{Fe}, \mathrm{Zn}, \mathrm{Cd}, \mathrm{Mn}, \mathrm{Pb}, \mathrm{Cr}, \mathrm{Ni}$, and Co concentrations were determined in the fishes and sediments of two estuaries. In station 1, accumulation of Fe was found to be higher followed by $\mathrm{Zn}, \mathrm{Cd}$, and $\mathrm{Mn}$ while $\mathrm{Pb}, \mathrm{Cr}, \mathrm{Ni}$, and $\mathrm{Co}$ were Below Detectable Level (BDL) (Table 4). At Station 2, Cd was found to be a primary pollutant followed by $\mathrm{Fe}, \mathrm{Zn}$, and $\mathrm{Mn}$ and $\mathrm{Pb}, \mathrm{Cr}, \mathrm{Ni}$, and $\mathrm{Co}$ are in the BDL (Table 5). 
Table 1 Fishes within feasible size range were used for the determination of metals

\begin{tabular}{|c|c|c|c|c|}
\hline S. no. & Name of the species & Size range $(\mathrm{cm})$ & Mode of life & Feeding behavior \\
\hline 1 & Mugil cephalus & $14.5-15.2$ & Benthopelagic & Heterotroph \\
\hline 2 & Oreochromis mossambicus & $10.3-10.8$ & Benthopelagic & Omnivores \\
\hline 3 & Arius caelatus & $11.4-11.6$ & Pelagic & Detrivore and carnivore \\
\hline 4 & Chanos chanos & $25.0-26.4$ & Epipelagic & Carnivore \\
\hline 5 & Lutjanus fulviflamma & $28.0-29.2$ & Epipelagic & Carnivore \\
\hline 6 & Terapon jarbua & $34.2-36.0$ & Epipelagic & Carnivore \\
\hline
\end{tabular}

Depending upon the overall average mean value of each metal, the metal accumulation was in the order of $\mathrm{Fe}>\mathrm{Zn}>\mathrm{Cd}>\mathrm{Mn}>\mathrm{Pb}>\mathrm{Cr}>\mathrm{Ni}>\mathrm{Co}$ at Station 1, and in the Station 2 samples were in the order: $\mathrm{Cd}>\mathrm{Fe}>$ $\mathrm{Zn}>\mathrm{Mn}>\mathrm{Pb}>\mathrm{Cr}>\mathrm{Ni}>\mathrm{Co}$.

The metal concentration and the corresponding mean standard deviations all the samples from both estuaries are shown in Tables 4 and 5 . Concentration of the heavy metals significantly varied in the samples collected from the two stations. In station 1, the concentration of Cd ranged from $0.02 \pm 0.01$ (A. caelatus) to $2.1 \pm 0.3$ (O. mossambicus) $\mu \mathrm{g} / \mathrm{g}$, for Co $0.008 \pm 0.062$ (M. cephalus) to $0.17 \pm 0.2$ (L. fulviflamma) $\mu \mathrm{g} / \mathrm{g}$, for $\mathrm{Cr} 0.1 \pm 0.07$ (L. fulviflamma) to $0.44 \pm 0.53$ (sst 2) $\mu \mathrm{g} / \mathrm{g}$, for Fe $3.8 \pm$ 0.16 (C. chanos) to $19.8 \pm 0.58$ (O. mossambicus) $\mu \mathrm{g} / \mathrm{g}$, for $\mathrm{Mn} 0.20 \pm 0.02$ (sst 2) to $1.2 \pm 0.34$ (L. fulviflamma) $\mu \mathrm{g} / \mathrm{g}$, for $\mathrm{Ni} 0.03 \pm 0.01$ (A. caelatus) to $0.33 \pm 0.40$ (O. mossambicus) $\mu \mathrm{g} / \mathrm{g}$, for $\mathrm{Pb} 0.05 \pm 0.03$ (A. caelatus) to $1.94 \pm 0.01$ (sst 2) $\mu \mathrm{g} / \mathrm{g}$, and for $\mathrm{Zn} 1.24 \pm 0.12$ (C. chanos) to $7.1 \pm 0.9$ (L. fulviflamma) $\mu \mathrm{g} / \mathrm{g}$.

In station 2, the concentration of $\mathrm{Cd}$ ranged from $1.12 \pm$ 0.012 (sst 1) to $26.25 \pm 0.063$ (O. mossambicus) $\mu \mathrm{g} / \mathrm{g}$, for Co $0.006 \pm 0.003$ (C. chanos) to $0.049 \pm 0.05$ (O. mossambicus) $\mu \mathrm{g} / \mathrm{g}$, for $\mathrm{Cr} 0.055 \pm 0.005$ (M. cephalus) to $0.21 \pm 0.04$ (C. chanos) $\mu \mathrm{g} / \mathrm{g}$, for Fe $3.171 \pm 0.05$ (A. caelatus) to $26.58 \pm 2.6$ (sst 1) $\mu \mathrm{g} / \mathrm{g}$, for Mn $0.42 \pm 0.037$ (sst 2) to $1.38 \pm 0.28$ (A. caelatus) $\mu \mathrm{g} / \mathrm{g}$, for $\mathrm{Ni} 0.06 \pm 0.01$ (sst 1 ) to $0.13 \pm 0.012$ (sst 2) $\mu \mathrm{g} / \mathrm{g}$, for $\mathrm{Pb} 0.05 \pm 0.003$ (M. cephalus) to $0.78 \pm 0.16$ (sst 1) $\mu \mathrm{g} / \mathrm{g}$, and for $\mathrm{Zn} 1.319 \pm 0.04$ (M. cephalus) to $4.152 \pm 0.073$ (O. mossambicus) $\mu \mathrm{g} / \mathrm{g}$.

Metals like $\mathrm{Fe}, \mathrm{Zn}$, and $\mathrm{Mn}$ were commonly found in all the fish samples, but $\mathrm{Cd}$ showed the maximum accumulation in Station 2. In case of sediment, there is no much variation in metal accumulation, but Fe, $\mathrm{Zn}$, and

Table 2 Operating parameters for the Inductively Coupled Plasma Optical Emission Spectrometer

\begin{tabular}{|c|c|}
\hline Parameters & Conditions \\
\hline Plasma capacity (W) & 1300 \\
\hline Plasma flow rate (L minÀ1) & 15 \\
\hline 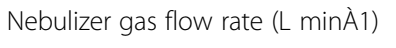 & 0.8 \\
\hline Sample flow rate (mL minÀ1) & 1.5 \\
\hline
\end{tabular}

Cd relatively showed maximum concentration at both Stations. But in station 2, Cd concentration in fishes was higher than the sediment samples.

Dendrograms (Figures 1 and 2) are drawn to identifying the percentage of pollution by metals at each station using of group linkage clustering technique (Bray Curtis Similarity coefficient of similarity). $\mathrm{Cr}$ and $\mathrm{Pb}$ pollutions were at the highest level of (85.56\%) of similarity at station 1, Cd and Mn were successfully grouped by the next level of similarity (70.31\%). At station 2 same $\mathrm{Cr}$ and $\mathrm{Pb}$ were polluted at the highest level of similarity (84.26\%), Co and Ni showed a second level of similarity (77.29\%).

\section{Discussion}

Our study reported that the accumulation of $\mathrm{Cd}, \mathrm{Cr}, \mathrm{Ni}$, and $\mathrm{Mn}$ were exceeding the maximum permissible limit (Tables 4 and 5) and the study stations might face high level risk from metal pollution in the future. In aquatic ecosystems, fishes are considered as good representative indicators of the overall system of health, due to their relatively higher position occupied in the food-chain [12]. Marine organisms, including fish, accumulate heavy metals through direct absorption, or via food chain, and pass them to human beings by consumption, causing acute chronic or disorders [13]. Numerous reports describe the accumulation of metal residues in wild marine fish species [14].

\begin{tabular}{ll}
$\begin{array}{l}\text { Table } 3 \text { Wavelength used for ICP-OES analysis for each } \\
\text { metal }\end{array}$ \\
\hline Elements & Wave length \\
\hline $\mathrm{Cd}$ & 228.802 \\
$\mathrm{Co}$ & 228.616 \\
$\mathrm{Cu}$ & 324.752 \\
$\mathrm{Fe}$ & 238.204 \\
$\mathrm{Mg}$ & 285.213 \\
$\mathrm{Mn}$ & 259.372 \\
$\mathrm{Ni}$ & 231.604 \\
$\mathrm{~Pb}$ & 220.353 \\
$\mathrm{Zn}$ & 213.857 \\
\hline
\end{tabular}


Table 4 Metal concentration in the station 1 samples

\begin{tabular}{|c|c|c|c|c|c|c|c|c|c|}
\hline \multirow[t]{2}{*}{ Metals } & \multicolumn{6}{|c|}{ Fish samples $(\mu \mathrm{g} / \mathrm{g})$} & \multicolumn{2}{|c|}{ Sediment samples $(\mu \mathrm{g} / \mathrm{g})$} & \multirow{2}{*}{$\begin{array}{l}\text { WHO/EPA } \\
\text { standard }\end{array}$} \\
\hline & $\begin{array}{l}\text { M. cephalus } \\
\text { (Mean } \pm \text { SD) }\end{array}$ & $\begin{array}{l}\text { O. mossambicus } \\
\text { (Mean } \pm \text { SD) }\end{array}$ & $\begin{array}{l}\text { A. caelatus } \\
\text { (Mean } \pm \text { SD) }\end{array}$ & $\begin{array}{l}\text { C. chanos } \\
\text { (Mean } \pm \text { SD) }\end{array}$ & $\begin{array}{l}\text { L. fulviflamma } \\
\text { (Mean } \pm \text { SD) }\end{array}$ & $\begin{array}{l}\text { T. jarbua } \\
\text { (Mean } \pm \text { SD) }\end{array}$ & $\begin{array}{l}\text { Sst1 } \\
\text { (Mean } \pm \text { SD) }\end{array}$ & $\begin{array}{l}\text { Sst } 2 \\
(\text { Mean } \pm \text { SD) }\end{array}$ & \\
\hline $\mathrm{Cd}$ & $0.13 \pm 0.049$ & $2.13 \pm 0.368$ & $0.02 \pm 0.01$ & $0.23 \pm 0.09$ & $0.06 \pm 0.02$ & $0.1 \pm 0.27$ & $3.9 \pm 0.25$ & $1.5 \pm 0.27$ & $0.0-0.2$ \\
\hline $\mathrm{Co}$ & $0.008 \pm 0.002$ & $0.04 \pm 0.004$ & $0.12 \pm 0.05$ & $0.02 \pm 0.001$ & $0.17 \pm 0.02$ & $0.05 \pm 0.003$ & $0.03 \pm 0.006$ & $0.03 \pm 0.01$ & - \\
\hline $\mathrm{Cr}$ & $0.13 \pm 0.05$ & $0.11 \pm 0.003$ & $0.13 \pm 0.04$ & $0.11 \pm 0.004$ & $0.1 \pm 0.07$ & $0.12 \pm 0.07$ & $0.34 \pm 0.08$ & $0.44 \pm 0.05$ & $0.1-0.15$ \\
\hline $\mathrm{Fe}$ & $14.9 \pm 0.25$ & $19.97 \pm 0.54$ & $10.3 \pm 0.24$ & $3.8 \pm 0.16$ & $13.2 \pm 1.7$ & $5.2 \pm 0.9$ & $12.1 \pm 0.4$ & $9.0 \pm 0.14$ & $4-48.0$ \\
\hline $\mathrm{Mn}$ & $0.9 \pm 0.14$ & $1.2 \pm 0.34$ & $0.3 \pm 0.04$ & $0.3 \pm 0.07$ & $0.1 \pm 0.05$ & $0.03 \pm 0.01$ & $1.1 \pm 0.11$ & $0.2 \pm 0.02$ & $0.0025-0.00$ \\
\hline $\mathrm{Ni}$ & $0.31 \pm 0.03$ & $0.33 \pm 0.01$ & $0.04 \pm 0.04$ & $0.05 \pm 0.002$ & $0.1 \pm 0.03$ & $0.1 \pm 0.07$ & $0.06 \pm 0.015$ & $0.05 \pm 0.034$ & $0.0-0.140$ \\
\hline $\mathrm{Pb}$ & $0.10 \pm 0.08$ & $0.13 \pm 0.001$ & $0.05 \pm 0.03$ & $0.08 \pm 0.02$ & $0.25 \pm 0.2$ & $0.4 \pm 0.05$ & $0.185 \pm 0.08$ & $0.0536 \pm 0.005$ & $0-1.5$ \\
\hline $\mathrm{Zn}$ & $2.25 \pm 0.10$ & $2.26 \pm 0.34$ & $2.01 \pm 0.45$ & $1.24 \pm 0.12$ & $7.1 \pm 0.9$ & $1.6 \pm 0.8$ & $2.28 \pm 0.02$ & $2.9 \pm 0.13$ & $58-150$ \\
\hline
\end{tabular}

Sst1 Sediment site 1; Sst2 Sediment site 2.

From the observations, sediment samples of station 1, the level of $\mathrm{Cd}$ and $\mathrm{Mn}$ was higher in site 1 compared to site 2, whereas $\mathrm{Zn}$ and $\mathrm{Pb}$ were higher in site 2 than site 1. Similar distributions of metals were observed in fish samples of both sites of station 2 . These results indicated that site 1 (stacknend) was more polluted than site 2 (bar mouth) because all the waste and industrial effluents were entered through site1 (stacknend).

The different forms and concentration of heavy metals in the sediment of an aquatic medium determine their bioavailability and toxicity. Thus, the study of the different fractions of the elements in the sediment was vital because the total concentrations are not representative of the real degree of the potential contamination. Heavy metals can be bound to or occluded in amorphous materials, adsorbed on clay surfaces or iron/manganese oxyhydroxides, co-precipitated in secondary minerals such as carbonates, sulfates, or oxides, complexes with organic matter, or included in the lattice of primary minerals such as silicates [15].

In the current study, heavy metal concentrations in sediment were found to be higher in for fishes at both stations. As such, accumulation of heavy metals in tissue depends mainly on metal concentration in sediment. This shows that Stacknend station was more polluted than the Barmouth. The sediment samples also reflected the same trend.

Metal Pollution Index (MPI) (safe limits) of WHO distinguishes polluted from unpolluted ecosystems, based on acquired knowledge on metal bio-availability, bio-concentration and bioaccumulation patterns [16]. Results of our study shows, fish samples such as $M$. cephalus, O. mossambicus, A. caelatus, and C. chanos, T. jarbua and L. fulviflamma collected from station $1, \mathrm{Fe}$ and $\mathrm{Zn}$ accumulated highest concentration, whereas Co and $\mathrm{Pb}$ had the lowest among all eight metals analyzed. But based on WHO/USEPA reference standard for fish [17] (Table 4), Cd, Mn and Ni were the major pollutant in station 1 . In O. mossambicus and C. chanos, the $\mathrm{Cd}$ (2.128 and $0.238 \mu \mathrm{g} / \mathrm{g}$ ) was found higher than the standard value of WHO/USEPA. But Mn $(0.859,1.252,0.283$ and $0.276 \mu \mathrm{g} / \mathrm{g})$ and $\mathrm{Ni}(0.314,0.327,0.038$ and $0.036 \mu \mathrm{g} / \mathrm{g}$ ) were found to be in an elevated state (concentration) than the standard value in all fish samples of

Table 5 Metal concentration in the station 2 samples

\begin{tabular}{|c|c|c|c|c|c|c|c|c|c|}
\hline \multirow[t]{2}{*}{ Metals } & \multicolumn{6}{|c|}{ Fish samples $(\mu \mathrm{g} / \mathrm{g})$} & \multicolumn{2}{|c|}{ Sediment samples $(\mu \mathrm{g} / \mathrm{g})$} & \multirow{2}{*}{$\begin{array}{l}\text { WHO/EPA } \\
\text { standard }\end{array}$} \\
\hline & $\begin{array}{l}\text { M. cephalus } \\
\text { (Mean } \pm \text { SD) }\end{array}$ & $\begin{array}{l}\text { O. mossambicus } \\
\text { (Mean } \pm \text { SD) }\end{array}$ & $\begin{array}{l}\text { A. caelatus } \\
(\text { Mean } \pm \text { SD) }\end{array}$ & $\begin{array}{l}\text { C. chanos } \\
\text { (Mean } \pm \text { SD) }\end{array}$ & $\begin{array}{l}\text { L. fulviflamma } \\
\text { (Mean } \pm \text { SD) }\end{array}$ & $\begin{array}{l}\text { T. jarbua } \\
\text { (Mean } \pm \text { SD) }\end{array}$ & $\begin{array}{l}\text { Sst1 } \\
\text { (Mean } \pm \text { SD) }\end{array}$ & $\begin{array}{l}\text { Sst } 2 \\
(\text { Mean } \pm \text { SD) }\end{array}$ & \\
\hline $\mathrm{Cd}$ & $16.5 \pm 0.4$ & $26.25 \pm 0.06$ & $6.95 \pm 0.21$ & $14.4 \pm 0.197$ & $3.31 \pm 0.5$ & $0.9 \pm 0.4$ & $1.12 \pm 0.01$ & $1.83 \pm 0.06$ & $0.0-0.2$ \\
\hline Co & $0.07 \pm 0.002$ & $0.05 \pm 0.004$ & $0.01 \pm 0.001$ & $0.02 \pm 0.003$ & $0.04 \pm 0.02$ & $0.03 \pm 0.02$ & $0.02 \pm 0.001$ & $0.03 \pm 0.01$ & - \\
\hline $\mathrm{Cr}$ & $0.06 \pm 0.005$ & $0.09 \pm 0.006$ & $0.16 \pm 0.04$ & $0.8 \pm 0.014$ & $0.31 \pm 0.1$ & $0.22 \pm 0.05$ & $0.17 \pm 0.008$ & $0.19 \pm 0.07$ & $0.1-0.15$ \\
\hline $\mathrm{Fe}$ & $1.5 \pm 0.053$ & $3.9 \pm 0.034$ & $3.2 \pm 0.05$ & $3.5 \pm 0.01$ & $5.7 \pm 0.9$ & $6.2 \pm 2.1$ & $26.6 \pm 2.6$ & $12.9 \pm 1.2$ & $4-48.0$ \\
\hline $\mathrm{Mn}$ & $0.18 \pm 0.003$ & $0.67 \pm 0.11$ & $0.8 \pm 0.03$ & $0.6 \pm 0.01$ & $0.4 \pm 0.3$ & $0.2 \pm 0.1$ & $0.5 \pm 0.16$ & $0.42 \pm 0.03$ & $0.0025-0.005$ \\
\hline $\mathrm{Ni}$ & $0.02 \pm 0.002$ & $0.04 \pm 0.004$ & $0.03 \pm 0.003$ & $0.03 \pm 0.002$ & $0.06 \pm 0.09$ & $0.05 \pm 0.03$ & $0.06 \pm 0.01$ & $0.13 \pm 0.01$ & $0.0-0.140$ \\
\hline h & $0.05 \pm 0.003$ & $0.08 \pm 0.005$ & $0.09 \pm 0.003$ & $0.06 \pm 0.003$ & $0.4 \pm 0.09$ & $0.07 \pm 0.01$ & $0.8 \pm 0.16$ & $0.5 \pm 0.36$ & $0-1.5$ \\
\hline n & $1.33 \pm 0.04$ & $4.15 \pm 0.073$ & $2.4 \pm 0.121$ & $2.04 \pm 0.10$ & $2.7 \pm 0.31$ & $1.7 \pm 0.6$ & $3.0 \pm 0.20$ & $2.15 \pm 0.43$ & $58-150$ \\
\hline
\end{tabular}

Sst1 Sediment site 1; Sst2 Sediment site 2. 


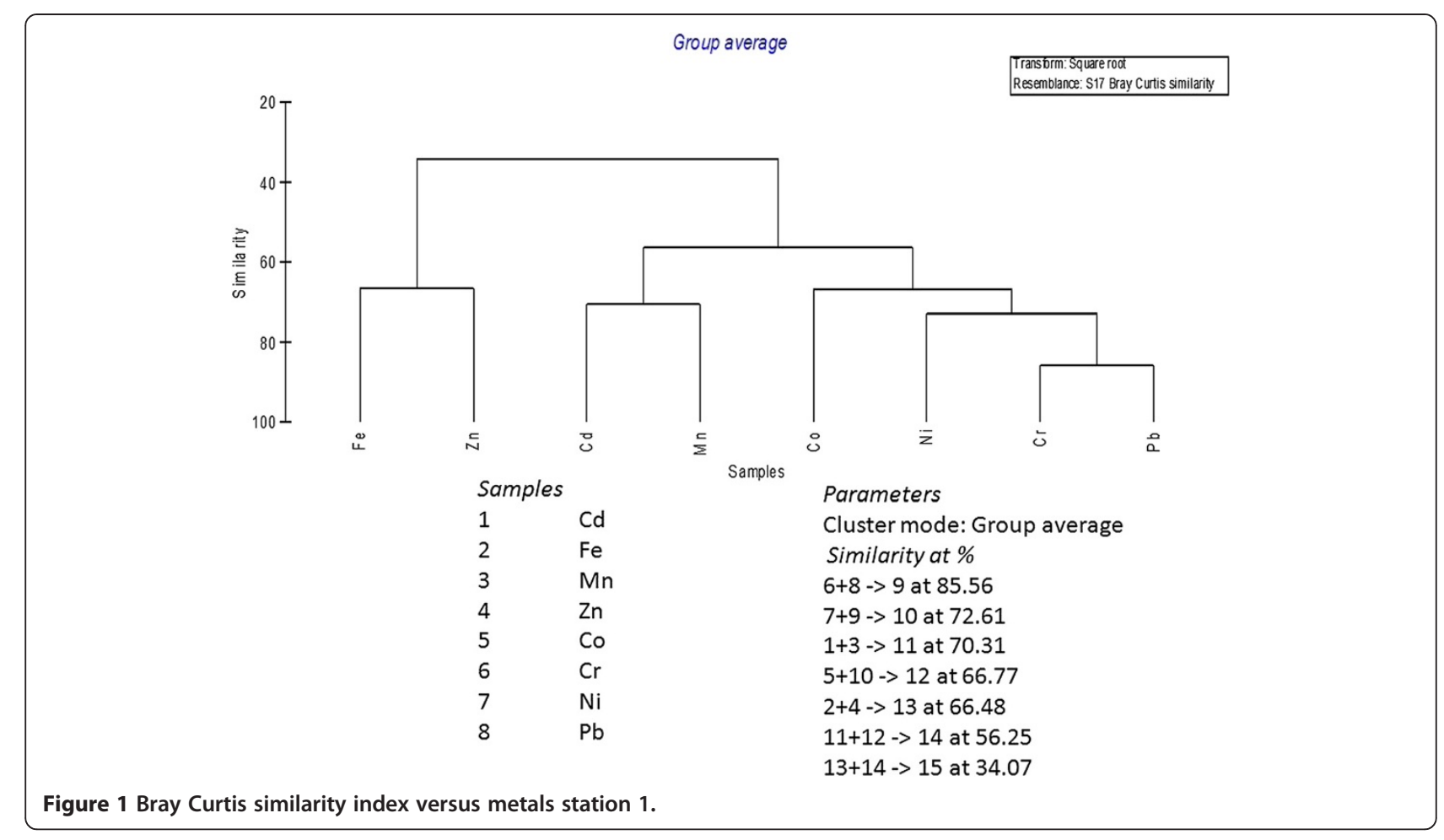

Station 1. The levels of $\mathrm{Fe}, \mathrm{Zn}, \mathrm{Pb}, \mathrm{Cr}$, and $\mathrm{Co}$ were found were found to fall within WHO/EPA safe limits. Fish samples collected from Station 2, concentration of $\mathrm{Cd}$ was higher than other metals and Co was at the lowest concentration. These results are indicative that $\mathrm{Cd}$
(16.69, 46.3, 6.94 and $14.37 \mu \mathrm{g} / \mathrm{g}), \mathrm{Mn}(0.181,0.698$, 0.794 and $0.642 \mu \mathrm{g} / \mathrm{g})$, and $\mathrm{Cr}(0.155 \mu \mathrm{g} / \mathrm{g})$ were relatively higher than the standard value (Table 5).

Metals like $\mathrm{Fe}, \mathrm{Cu}, \mathrm{Zn}$, and $\mathrm{Mn}$ are the essential metals for life, whereas $\mathrm{Ni}, \mathrm{Pb}, \mathrm{Co}$, and $\mathrm{Cd}$ are toxic even in

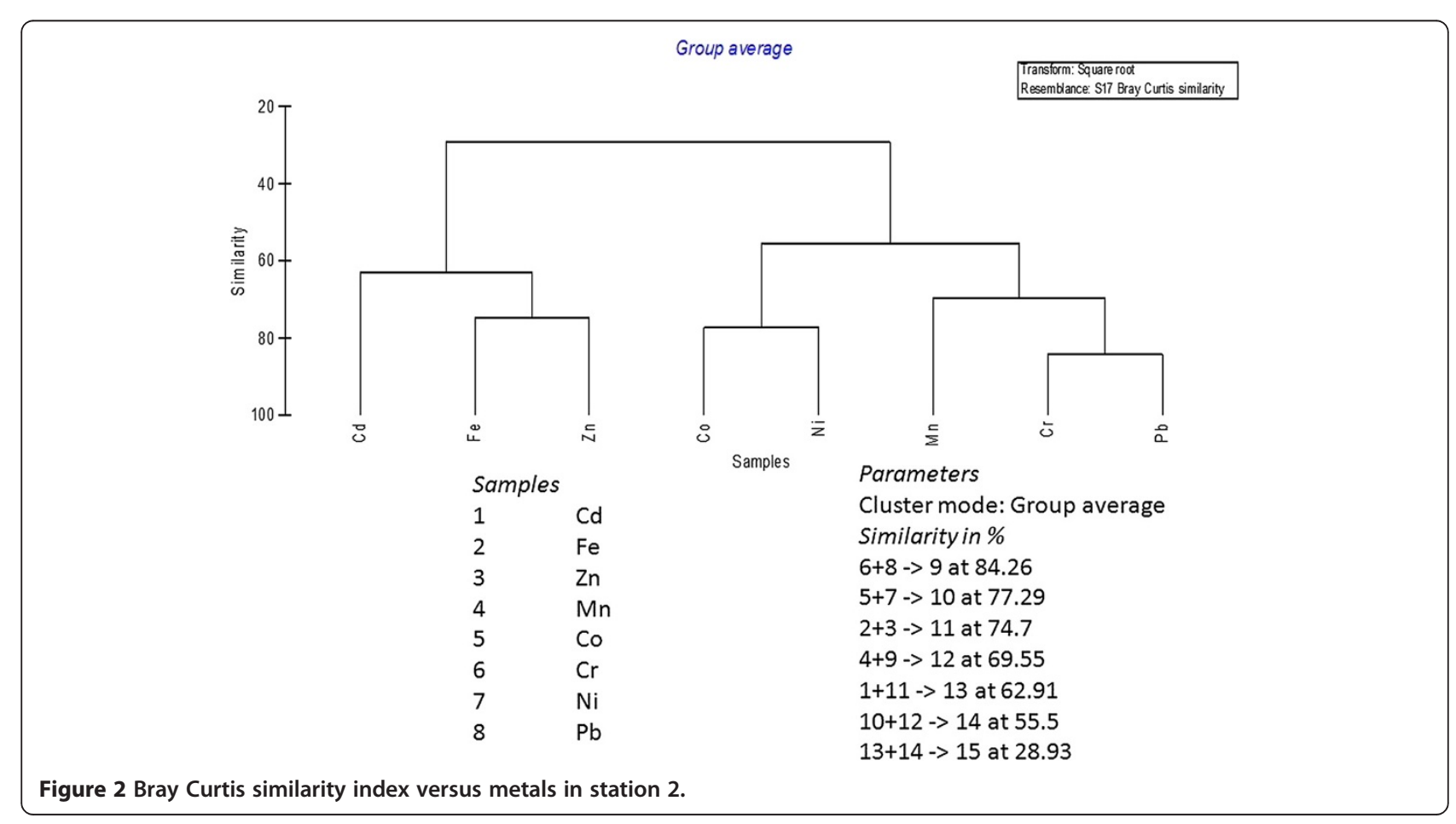


trace amounts. Lakshmanasenthil et al., (2012) [18] reported that the $\mathrm{Cd}$ accumulation (1.11, 3.85 and $2.53 \mu \mathrm{g} / \mathrm{g}$ ) in different organs of same species from Nagoor estuary, Bay of Bengal. It has been shown that that $\mathrm{Cd}$ was the major pollutant of that area and that it is has been proved that $\mathrm{Cd}$ accumulation in fishes will lead to their liver damage.

Vinodhini and Narayanan (2008) [19] also proved the high concentration of $\mathrm{Cd}(1.883,1.693$ and $1.166 \mu \mathrm{g} / \mathrm{g})$ alters the metabolic functions of Cyprinus carpio fish. Metal contaminants eventually find their way into the human system through the food chain [20], Harvey (1975) [21] reported the death of human who consume Cd-polluted fish from the Jintsu River estuary in Japan. The present research showed that concentration of $\mathrm{Cd}$ in the sample is at an alarming level which may affect total environment and cause dangerous consequences.

Harvey (1975) [21] reported that the Mn concentration has been shown to accumulate in the kidney, bone, liver tissues and also induces sexual excitement and impotence of marine fishes. Indrajit et al., (2011) [22] explained the pollution of $\mathrm{Mn}$ (5.14, $1.19 \mu \mathrm{g} / \mathrm{g}$ etc.,) in Yamuna river by fishes. Thiyagarajan et al., (2012) [23] showed cadmium, chromium, manganese and mercury concentration of five marine fish species (Epinephelus chlorostigma, Lutjanus russelli, Terapon jarbua, Cynoglossus arel and Lagocephalus lunaris) varied from $0.274 \pm 0.03$ to $53.39 \pm 14.3 \mu \mathrm{g} / \mathrm{g}$ which led to total environment pollution in Cuddalore, nearest place of our study stations. Nickel is a hazardous element notified by the USFDA (1993) [24], though not covered by EC regulations for fish and other aquatic products. However till now, no exact report has been made on the metal accumulation by the fish species selected for the present study. To the best of our knowledge, this is the first report on the metal accumulation of Mugil cephalus, Oreochromis mossambicus, Arius caelatus, Lutjanus fulviflamma, Terapon jarbua and Chanos chanos.

In our study, the concentrations of $\mathrm{Fe}, \mathrm{Zn}, \mathrm{Pb}$, and $\mathrm{Co}$ of both estuaries were in safe limit. Though these metals are within safe limit at present, there is an increasing chance that it might get increase in the near future, and turn toxic. Cobalt is one of the metal that is present naturally in the body, but in excess concentration, it becomes toxic and lead to harmful potentially permanent side effects like cardiomyopathy, hypothyroidism, and neurological damage as well as impairment of the senses [25]. Similarly, iron poisoning causes pain in the stomach, due to ulceration of stomach lining; which is accompanied by nausea and vomiting. Zinc toxicity is a rare phenomenon but it may induce toxicity when concentration increased to about $40 \mu \mathrm{g} / \mathrm{kg}$. In addition to this several in vitro studies indicated that high concentrations of chromium (III) in the cell can lead to DNA damage [24]. Chromium reaches the blood stream; it damages the kidneys, the liver, and blood cells through oxidation reactions. Lead is a nonessential toxic element which can cause defects in survival, growth rate, development, and metabolism in fishes [13]. These previous findings suggest that these metals turn toxic to humans when they get accumulated in excess level through food like fishes.

\section{Conclusion}

The results of this study provided valuable information about the metal contents in sediment and fish from the two estuaries of Bay of Bengal. Based on the findings, station 2 was more polluted than station 1 because of the high accumulation of $\mathrm{Cd}$. The marginally higher concentrations of $\mathrm{Cd}, \mathrm{Cr}$, and $\mathrm{Mn}$ in the samples collected from station 2 could be related to industrialization and related anthropogenic activities in these areas. Moreover, these results enable us to understand the chemical quality of fish and to evaluate the possible risk associated with their consumption. This study emphasizes that $\mathrm{Cd}$ and $\mathrm{Mn}$ levels in both stations, are higher than the acceptable values for human consumption set by various health organizations and presents a greater human health issue in the future. These results insist that station 2 should be monitored on a regular basis for more possible metal toxicity. Besides, further studies are needed to evaluate and to characterize the fishes in the estuary relative to specific metal pollutants because the Cd level in fishes of station 2 and Fe level in fishes of station 1 were higher compared to sediment. This study is an indication of high contamination of water resource due to the anthropogenic sources and the competent monitoring program is an essential adjunct to any attempt of managing the coastal areas in an ecologically sound and sustainable manner.

\section{Competing interests}

All authors declare that they have no competing interest.

\section{Authors' contributions}

SL and TM were the main investigator, designed and performed the study and drafted the manuscript. TV and TTA supervised the study. KVD, JG and TB were advisors of the study. SG helped in the statistical analysis. All authors read and approved the final manuscript.

\section{Acknowledgement}

The authors are thankful to Saibaba, the authorities of Annamalai University and CMS college of Science and Commerce for their facilities.

\section{Author details}

${ }^{1}$ CMS College of Science and Commerce, Chinnavedampati (PO), Coimbatore, Tamil Nadu, India. ${ }^{2}$ Centre of Advanced Study in Marine Biology, Faculty of Marine Sciences, Annamalai University, Parangipettai 608 502, Tamil Nadu, India.

Received: 5 March 2013 Accepted: 25 September 2013 Published: 19 December 2013 


\section{References}

1. Matta J, Milad M, Manger R, Tosteson T: Heavy metals, lipid peroxidation and ciguatera toxicity in the liver of the Caribbean barracuda [Sphyraena barracuda]. Biol Trace Elem Res 1999, 70:69-79.

2. Lee YH, Stuebing RB: Heavy metal contamination in the River Toad, Bufo juxtasper (Inger), near a copper mine in East Malaysia. Bull Environ Contam Toxicol 1990, 45:272-279.

3. Ananthan G, Sampathkumar P, Palpandi C, Kannan L: Distribution of heavy metals in Vellar estuary, Southeast coast of India. J Ecotoxicol Environ Monit 2006, 16:185-191.

4. Karthikeyan R, Vijayalakshmi S, Balasubramanian T: Monthly variations of heavy metals and metal resistant bacteria from the Uppanar estuary (Southeast coast of India). Res J Microbiol 2007, 2:50-57.

5. Gibson RS: Content and bioavailability of trace elements in vegetarian diets. American J clin Nut 1994, 59:1223-1232.

6. Eugenia JO, Sanchez G, Marcado G: Cleaner production and environmental sound biotechnology for the prevention of upstream nutrient pollution in the Mexican coast of the Gulf of Mexico. Oce Coastal Manag 2004, 47:641-670.

7. Amundsen T, Forsgren $E$, Hansen LTT: On the function of female ornaments: male bluethroats prefer colourful females. Proc R Soc Lond Ser B 1996, 264:1579-1586.

8. Michael HC: Heavy metal. In Encyclopedia of Earth. Edited by Monosson Cleveland C. Washington DC: National Council for Science and the Environment: 2010.

9. Norhayati MT, Abdullah AR, Shanmugam S: Determination of total hydrocarbon concentration in coastal waters and sediments off the east coast of Peninsular Malaysia. Environ Geochem Health 1997, 19:67-69.

10. AOAC: AOAC official methods of analysis. 15th edition. Arlington, Virginia: Association of Official Analytical Chemists; 1990.

11. Dhaneesh KV, Gopi M, Ganeshamurthy R, AjithKumar TT, Balasubramanian T: Bio-accumulation of metals on reef associated organisms of Lakshadweep Archipelago. Food Chem 2011, 131:985-991.

12. Adams SM, Brown AM, Goede RW: A quantitative health assessment index for rapid evaluation of fish condition in the field. Trans Am Fish Soc 1993, 122:63-73.

13. Eastmond David A, MacGregor JT, Slesinski RS: Trivalent chromium: assessing the genotoxic risk of an essential trace element and widely used human and animal nutritional supplement. Crit Rev Toxicol 2008, 38(3):173-190

14. Cogun HY, Yuzereroglu TA, Kargin F, Firat O: Metal concentrations in fish species from the northeast Mediterranean Sea. Environ Monit Assess 2006, 121:431-438.

15. Peng JF, Song YH, Yuan P: The remediation of heavy metals contaminated sediment. J Haz Mat 2009, 161(2-3):633-640.

16. Teodoravic I, Djukic N, Matetin B, Miljunovic I, Juguvac N: Metal pollution index: proposal for freshwater monitoring based on trace metal accumulation in fish. Tiscia 2000, 32:55-60.

17. Storelli MM, Barone G, Storelli A, Marcotrigio GO: Trace metals in tissues of Mugilids (Mugil auratus, Mugil capito and Mugil labrosus) from the Mediterranean Sea. Bull Environ Conta Toxicol 2006, 77:43-50

18. Lakshmanasenthil S, AjithKumar TT, MaruthuPandi T, Dhaneesh KV, Balamurugan J, Balasubramanian T: Metals contagion in ecologically important estuary located in Bay of Bengal. Water Qua Expo Health 2012 doi: 10.1007/s12403-012-0072-0 (online).

19. Vinodhini R, Narayanan M: Bioaccumulation of heavy metals in organs of fresh water fish Cyprinus carpio (Common carp). Int J Environ Sci Tech 2008, 5(2):179-182

20. Obodo GA: The bioaccumulation of heavy metals in fish from the lower Reaches of River Niger. J Chem Soc Nigeria 2002, 27(2):173-176.

21. Harvey S: Heavy metals. In Pharmacological basis of therapeutics. fifthth edition. Edited by Goodman LS, Gilman A. New York: Macmillan; 1975.

22. Indrajit S, Ajay S, Shrivastava VS: Physico-chemical analysis of underground water of Harihara Taluk of Davanagere District, Karnataka. India. Adv Appl Sci Res 2011, 2(2):161-166.

23. Thiyagarajan B, Dhaneesh KV, Ajith Kumar TT, Kumaresan S, Balasubramanian T: Metals in Fish along the Southeast Coast of India. Bull Environ Conta Toxicol 2012, 88:582-588.
24. USFDA: Chromium in Shellfish. Food and Drug Administration. Washington, DC: Guidance Document for DHHS/PHS/FDA/CFSAN/ Office of Seafood; 1993.

25. Dhaneesh KV, Gopi M, Ganeshamurthy R, AjithKumar TT, Balasubramanian T: Determination of metal levels in thirteen fish species from lakshadweep sea. Bull Environ Contam Toxicol 2012, 88:69-73.

doi:10.1186/2052-336X-11-33

Cite this article as: Lakshmanasenthil et al:: Harmful metals concentration in sediments and fishes of biologically important estuary, Bay of Bengal. Journal of Environmental Health Sciences \& Engineering 2013 11:33.

\section{Submit your next manuscript to BioMed Central and take full advantage of:}

- Convenient online submission

- Thorough peer review

- No space constraints or color figure charges

- Immediate publication on acceptance

- Inclusion in PubMed, CAS, Scopus and Google Scholar

- Research which is freely available for redistribution

Submit your manuscript at www.biomedcentral.com/submit
() Biomed Central 